\title{
Are We Done Yet? A Critical Analysis of Promoting Student Engagement Inan Era of Accountability in Myanmar
}

\author{
Dr. Teck Choon TEO, DBA \\ Associate Dean, RVi Institute \\ Mandalay, Myanmar \\ Fellow, Chartered College of Teaching UK
}

\begin{abstract}
We live in a very complicated world characterised by the rapid pace of technological changes, the ever changing demand of skillsets in the workforce, the democratisation of learning etc. Given this backdrop, it is essentialfor educators and managers in the Myanmar education system to re-assess the need to recalibrate the system.In preparing for the future generation of learners in Myanmar schools, MCTA is a renewed institution, looking backward and forward, remembering the pain and loss of the past educational system and resolving to co-create a brighter future for all Myanmar people. In today's pedagogical approaches, engaging students in the learning process has long been central to the mission and purpose of education. It enhances their attention and focus, inspires them to have higherlevel critical thinking skills and consequently promotes purposeful learning experiences. In recent years, however, there has been a renewed focus on the role of education can play in preparing students for productive lives as citizens.
\end{abstract}

Keywords: Active learning,Flipping the classroom, Leading dynamic discussions, Community partnership, New ways of learning

\section{Introduction}

According to the Myanmar MOE (Ministry of Education), the desired outcomes of national education are critical thought, conscience and intelligencethat educators aspire for every Myanmar citizen to have by the completion of his/her formal education (Myanmar MOE 2016). These outcomes establish a common purpose for educators, driving policies and programmes, allowing for MOE to determine how well the education system is doing. The person who is schooled in the Myanmar education system exemplifiesfundamentals such as values, literacy and numeracy, offer variegated paths that support the specific talents and interests of students, and enact lessons in a way that spur curiosity and wonder in the youth, and make their eyes sparkle. To this end, he/she has a good sense of self-awareness, a sound moral compass, and the necessary skills and knowledge to take on challenges of the future. He/she is responsible to his/her family, community and nation. He/she appreciates the splendor of the world around him/her, possesses a healthy mind and body, and has a zest for life.

\section{Promoting student engagement through active learning}

In all active learning it is imperative that teachers engage the learners. However, this is getting more challenging in particular the classroom delivery, as teachers have to contend with current from technology in the classroom and diminishing attention spans frommillennials. While educators have been proponents of active learning for quite some time (Albert \& Beatty,2014; Bonwell\&Eison, 1991; Khan, Grube, Bernard \& McCann, 2013), teachers face a specific challenge in engagingstudents who have grown up jumping constantly from one activity or application to another.A growing concern on educating the modern digital learner is being raised. The explosionof technology has given birth to the biggest generational gap since the 1950s musical styles such as jazz, rhythm and blues, along with country music; howeverthe educational arena has yet to develop teaching and learning strategy to match the millennial generation. Schools in Myanmar generally restrict the use of technology in the classroom although wellintentioned, has failed to build a connection between the classroom and reality. Education has been a basis ofhuman life and success, and if educators are to keep the interest of the youth, adaptation and modification are obligatory.

Originally, Bloom's taxonomy was one-dimensional with an exclusive focus on the knowledge domain but educators use Bloom's Taxonomy and Bloom's Revised Taxonomy (two-dimensional) as a necessary and vital hierarchical instructional set of cognitive processes designed to structure appropriate learning experiences with the hope of positive academic outcomes for their students(Anderson and Krathwohl 2001, Krathwohl 2002, Growe 2011,). It is no secret that many forms of technology (i.e. wikis, blogs, education games, apps, etc.) exist and are available to students at little or no cost. 
However, if educators were to use these forms of technology correctly or in conjunction with lesson planning, the bridge between education and technology would be lessened. The argument is that technological novelties must be adapted into instructional tools otherwise it will not be helpful. Conversely, teachers must conjointly become 21 st century educators. Collaboration is not only a 21 st century skill but considered crucial in effective student engagement (Churches, 2009).Collaborationhere does not refer to people working together, but rather the fusion of traditional frameworks and theories with technology to augment the learning experience and excite student curiosity. Sir Ken Robinson rightly concluded the role of education by reiterating "Education is not only a preparation for what may come later; it is also about helpingpeople engage with the present" (Robinson, 2011, p. 59).

Indeed contemporary learners including millennials enjoy experiential learning or learning by doing (Kolb, 1984; Phillips\&Trainor, 2014; Roehl, Reddy \& Shannon, 2013). Experiential learning enables learners to engage in thelearning process through active participation and activities involving critical thinking. Learners also engage withtheir peers, receive feedback from teacher and reflect on their experiences. Converselyteachers think of integrating active learning strategies into lesson delivery, setting clear expectations, designing effective evaluation strategies and provide helpful feedback.By having a great learning experience, there is a positive relationship between the learner and the teacher or other caring adult. There are several pedagogical approaches tolearning, for example the flipped classroom and Just-in-time teaching (often abbreviated as JiTT), allows learners to engage in active and experiential learning.

\section{Flipping the classroom}

A pedagogy-first approach to teaching in which in-class time is re-purposed for inquiry, discussion and application in order to better meet the needs of the individual learners. The Flipped Classroom is an approach that attempts to meet the needs of the learners in our individual schools and communities. An important implementation of the flip nevertheless, is to engage students in lessontopiceven before they come to class (Bergmann and Sams 2014), this is typically watching a lecture or an online video, and engaging with peers and instructors online before class. Hence, in most Flipped Classrooms, there is an active and intentional transfer of some of the information delivery to outside of the classroom with the goal of freeing up time to make better use of the face-to-face interaction in school.Practitioners of the various flipped classroom models are constantly tweaking, changing, rejecting, adding to, and generally trying to improve the model through direct experience with how effective it is for kids (Schell 2012).

\section{Just-in-time teaching (often abbreviated as JiTT)}

Gregor Novak and colleagues first came up with a teaching and learning strategy that cleverly trigger the effective/productive usage of class time for more active learning. JiTT relies on a feedback loop between web-based learning materials and the classroom (Novak et al., 1999). Students prepare for class by reading from the prescribed textbook and using other resources posted to the web and completing assignments on-line even before actual lesson in the classroom. In essence, students' work outside the classroom environment and this serves as preparation for more complete lesson in class. The students' answers are delivered to the instructor a few hours before class starts, allowing the instructor to adapt the lesson as needed. Importantly, JiTT allows the instructor to create an interactive classroom environment that emphasizes active learning and cooperative problem solving.

Interestingly, Kathleen Marrs and Gregor Novak suggest that Just-in-Time Teaching integrates additional features that are helpful for enhancing students' learning (2004). Firstly, JiTT need to incorporate active learning approaches by shifting the "content-transfer" element of the course to pre-class preparation and focusing class time on cooperative problem solving, JiTT encourages the active learning approaches that have been found to promote learning (National Research Council (NRC), 2000; Hake (1998); Paulson 1999, Udovic et al., 2002). Further JiTT must provide structured opportunities for students to actively construct new knowledge from prior knowledge.This theory of learning, coined "constructivism," was propagated by Piaget and others, and posits that learners build new understandings on existing attitudes, experiences, and knowledge (Kujawa and Huske, 1995). The notion of pre-existing misconceptions can impede the development of new, more accurate mental models. Hence, effective learning necessitatesthose learnersto unpack and challenge preexisting knowledge and misconceptions. Finally JiTT must provide prompt feedback vis-à-vis formative assessment is particularly valuable for learners because it offers opportunities for learners to re-calibrate their thinking prior to a summative assessment (such as a graded exam).Handelsman, Miller and Pfund (2007) also note that the line between active learning and formative assessment is blurry and hard to define; after all, teaching that promotes students' active learning asks students to do or produce something, which then can serve to help assess understanding.

\section{Engaging millennialstudents - Leading dynamic conversation}

Over the last few decades, there has been a decline in the Myanmar education system, but there is a critical flaw thathas been overlooked. 
Today's learners differ fundamentally in the way they learn and absorb information from the previous generation of learners. Theselearners epitomize the first generation to grow up with advanced versions of technology, specifically educationaltechnology (Prenksy, 2001).

Therefore, understandingthe different learners' types can facilitate constructing effective curricula. What are their aspirations? What stimulates them? What resources do they bring to the classroom? What challenges might they encounter in school? What is their cultural heritage? What dialects/languages do they speak in their homes? What are the dogmas and practices associated with education that are held by their families? For that reason, the first question that must be addressed is "Engaging millennial students that lead to dynamic conversation?"

While dynamic conversations can be a very effective in encouraging student learning, successful conversations rarely happen spontaneously. Preparing ahead of time will help educators delineate a clear focus for the conversation and set well-defined parameters. This will enable the class to address important topics from multiple perspectives, thus increasing learners' curiosity for, and engagement with, the lesson content.

\section{Why educators must engage millennia students differently?}

All learners must construct their own meaning from lessons by linking new information and concepts to what they already believe or have experienced (AAAS, 1990). Assimilation of real-world situations that are important to learners, or their community, contextualises instruction within the prior experiences of learners. Thus contextualised instruction provides a conceptual scaffold on which learners can hang new ideas (Rivet and Krajcik, 2008).

Educational researchers suggest that it is knowledge that is useful and transferable in daily life, and it drives students'response as they attempt to achieve their goals in their "out-of-school" life (Pellegrino \& Hilton2012, Basu and Barton, 2007). Learners' perception of new knowledge and skills; if a lesson is perceived by a learner as empowering them to shape their life, community, and world, they are more likely to accept the information and welcome related information and skills (Bouillion and Gomez, 2001).

\section{DiversityTeaching}

In their survey of teacher beliefs concerning minority students and students from low-income families, Bryan and Atwater (2002) highlightedshared misconceptions and related classroom responses that could adversely affect learning outcomes in diverse classrooms.

Firstly, students from culturally diverse backgrounds are less capable than other students. Those teachers, who hold this belief, whether explicitly or implicitly, tend to define less ambitious learning goals, provide students with less autonomy, allow less interaction between students, and tend to rely more heavily on passive teaching methods. In direct contrast, researchers have found that minority students respond most favorably to inquiry in which they have some degree of control, and resist lessons that they perceive as being imposed upon them (Moll et al., 1992, Loh and Teo 2017).Real-world problems with no clear answer, and with implications for the well-being of the community, are ideal for engaging a diverse class of urban students (Bouillion and Gomez, 2001; Buxton et al., 2008).

Secondly, teachers should treat all students the same, regardless of their class, gender, or race.This belief leads to teaching methods that do not take into account the lack of commonality in educational and cultural background in an urban classroom. Disparities in household income and familial accountabilitiesamongst students will result in variations in student schedules and time available for out-of-class school work. Accordingly, in curriculum design school should allow alternative activities and assessments so that students may better integrate educational responsibilities with domestic/financial responsibilities (Davies2006). Additionally, treating all students as the same ignores culturallyrelated variations in the character of learning-related social interactions. Uekawa et al (2007) found that Asians are the only major ethnic group that prefers individual work over group work due to the cultural value associated with bringing honor to the family through individual achievement.

\section{Community Partnership}

Fundamentally, community service projects should take place in ways that allow students to have significant community impact vis make a difference in the civic life of their communities and developing the combination of knowledge, skills, values and motivation to make that difference. This means that the service component should meet a public good as determined by an open and thoughtful collaboration between school and community partners (Bogotch 2002, Theoharis 2009).

Community voice in a community-based project has an influence on student cultural understanding, and can shape their experiential and ethical learning.For this learning to happen, community members should be involved in every stage of the project and course, when possible. 
It is imperative to encourage and support community involvement in project planning, student orientation, guest lectures, site visits, class discussions, progress reports, final presentations, and project evaluation. Not only does this permit greater cultural understanding and ethical development, but it ensures deeper community partnerships and more impactful projects (Auerbach 2012).Exposure to diversity has an impact on students, particularly individual outcomes, such as identity development and cultural understanding. Again, community involvement is important at every phase of a project to ensure that this learning can take place.

Apart from the above, there must be civic dissemination, so as to ensure community engagement and impact, the results of the project should be shared with stakeholders vis-à-vis general public, the school and civic communities. Without opportunities for students to reflect upon their community work in the context of school curriculum, the learning potential of community projects is somewhat muted. There should be some mechanism that encourages students to link their community experience to school curriculum and to reflect upon why the community work is important.

\section{Myanmar's Education Framework - Gaps and New Ways of Learning}

Central to the current Myanmar's education system has been the nation's thoroughly curated examination and rote learning format. While undoubtedly demanding that produced capable civil servants, the testing of learners' ability to apply learned knowledge has proved to be an effective driver excellent academic outcome and has catapulted Myanmar people to move up in the global education curve.

In revisiting the central issue of current method of assessment, is it too narrow? Why do we have assessment in the first place? Firstly, it is to measure the progress of the learner and provide appropriate support, so that they can so call "learn at their own pace" by streaming them, and secondly, deciding criteria for the next step allocation (i.e. Elementary to Intermediate school, Intermediate to Secondary school, Secondary to Tertiary levels for job market). "Assessment" is really a complex problem. Is it fair to say that for some students exams may not be the best form of assessment? Testing has shown to hinder creativity and original thinking, create stress among students and teachers, and fails to consider the growth/ improvement of the student as a whole (Beghetto 2005). Overall, there are other forms of assessments that could potentially be better suited to wider range of students that should be considered (Hui 2003, Nagel 2013).

As we know that the majority of Myanmar students (and parents) are focusing on grades, hence, it is the dominant measure of assessment. The current way of assessing students (predominately through examinations) has served the nation well. It is good at assessing student's ability to retain, understand and analyse information. However, it does not do so well in cultivating skills like resourcefulness, teamwork, creativity, presentation skills etc. Other forms of assessment may be better suited to cultivate these skills like group projects or research papers. While these activities do happen in the classroom, they are not included in our major assessments and are therefore underweighted by both students and teachers. This is especially important with the changing landscape of skills demanded, educational resources i.e. harnessing technology and the democratisation of information and learning we may want to shift the way we assess our students.

Currently, as students move from K-5 to grades 6-12 and on to higher education, creativity is increasingly treated as a desirable skill that one should possess. Both educators and parents foresee that the demand for creativity and creative thinking is growing to solve complex problems and to drive future economies; sadly, students are not equipped to lead the innovation of tomorrow.Against this backdrop, the new ways of learning therefore can and should eliminate midyear examinations for several other levels. This will mark a significant shift in the Myanmar's educational approach. How does these change impact young learners in the Myanmar's education? Conversely parents too are impacted by it.

\section{New Ways of Learning}

Traditionally, the introduction of rote learning begins when learners enter elementary school. This involves memorization, drilling and examinations. This academic rigour of which has been known to build students up to become highly disciplined young learners. Arguably, there have been benefits to this learning routine; however, the biggest drawback is that there is no deep learning; there is no opportunity for freedom and time to explore topics in greater depths. This exploration is key to the development of critical thinking (Hare 1999, Paul 2007, Elder and Paul 2010).

In retrospect, at elementary level (Primary 1 and 2), learners should be building collaboration skills, nurturing their curiosity and learning to reflect on their learning and the progress they have made. To that end, the courage to step away from examinations/assessments rudiments is a giant step towards encouraging holistic learning, where the hours freed can be paced out and channeled towards quality pedagogies focused on inculcating 21 st century competencies. Invariably this translates to placing an emphasis on not just the hard skills, but rather on the soft skills such as teamwork, problem-solving and emotional quotient. 
These skills are transferable and increasingly more relevant and lend credence to real-work employment. The change will also allow time for learners to self-assess, an important element to learning which can be overlooked in a busy classroom. Learning to assess oneself develops self-discovery and self-awareness. Learner self-assessment involves evaluating their own work and learning progress. Self-assessment is a valuable learning tool as well as part of an assessment process. Through self-assessment, learners canidentify their own skill gaps, where their knowledge is weak (Hughes199, Race 2001, Brew 2003). This self-assessment also makes learners more independent and autonomous, a crucial skill for their overall development in their academic years as well as their later professional careers (Brown 1994, Biggs 1999).

\section{Implications for Parents}

Historically, examinationshave been the strongest, if not the only indicator by which parents monitored their child's progress. Correspondingly, if grades did not improve over the period of time, the understanding was that the child had not made progress. But realistically, the child most likely did advance intellectually, the examinations was only validating specific knowledge rather than a consolidation of overall learning. Hence, the departure from the narrow focus on exam grades is thus a positive step towards demonstrating that learning isnot confined to school subjects and examination success. It is a reminder to parents that exam grades, while perhaps indicative of a child's academic performance are not a conclusive benchmarking of a child's overall growth and development. Intuitively, all parents wonder and worry about their children's academic performance out of love and the best intentions.

\section{Multimodal assessment}

Moving away from traditional form of assessment vis mid and final-term examination. Other forms of assessments can be considered into the major educational milestones vis Elementary, Intermediate and Secondary. For example, a student's grades could be made up of a final year exam, a group project and a take home research paper. Including other forms of assessments will allow cultivation of other skills that examinations may not be able to. It is noteworthy that the examples of present forms of assessments are rather conventional (presentation, research paper, group project). However, we should not limit new forms of assessment to the conventional ones, an example of an innovation would be using new technologies like virtual reality/augmented reality (VR/AR) to enable some assessments. For example, an assessment of a student in math could be using trigonometry to determine the height of a building. With VR actually visualising the building could enhance learning and engage the student; web-based tools (e.g., blogs, online forums, wikis, podcasts, etc.) supporting student learning in creative and innovative ways.Learning space (or network learning space) can meet the needs of personalised learning through learning interface, function, recording, reminder, etc. Additionally, learners can create their individual custom settings. In order to create independent, authentic, immersive learning environment, learning space allow for comprehensive, personalised services for learners. These services include online learning, flexible testing, interactive and collaborative learning, resource recommendation, etc. (Teo and Low 2018).

\section{Discussion and Implications}

In response to today's rapidly changing world, a shift in including alternative forms of assessments is for two important reasons. First it stands to reduce emphasis on examinations, and it would cultivate and celebrate different skills. This can be seen as an opportunity to reinvent education such that students, stakeholders like parents and the workforce may view it in a more palatable lens.(The author does not advocate MOE doing away with Grade 4, 8 government examinations and Grade 10 university entrance examination). Second having multiple assessments would allow Myanmar's MOE to be more responsive, for example, if an assessment or skillset is deemed outdated or irrelevant due to a breakthrough in technology, MOE is better positioned to swap out that assessment for another.

More importantly, the bold initiative of de-emphasising on exams is to free up more time in schools to further strengthen holistic development. Giving learners - self-discovery and a more engaged learning process. These changes will provide more opportunities for learner-centric delivery and learning strategies.

Conversely, it will lay a robust groundwork for nurturing life-long learning attitudes and skills that is crucial for learners in the 21 st century.

\section{More Parent-Teacher Interaction}

To facilitate and assist parents understanding of their child's progress without examination grades, increased interaction between parents and schools will be important. Teachers have a good idea of children's development even without assessments. Classes almost always have varied form of informal assessments and teachers notice how children progress in their classroom. During conversation with teacher, it is good for parents to ask specific questions such as "Is my child havingself-confidence in class? What can I do to help them feel more willing to contribute in class?" 
On the other hand, it is crucial for parents to engage their children in conversations about school. Specific questions such as "How are they coping in class? What do they like or dislike in school? What interests do they have?" are helpful and constructive. Recognising children's interest in certain topics and noticing aptitude for a subject will foster love and passion. This kind of encouragement has a much more enduring impact in the long term and interest could become an endeavor well worth pursuing.

\section{Conclusion}

In cutting down exams and testings, the learning of students (in Grade 4, 8 and 10) will continue to be evaluated through homework and assessments, the change is that such assessments no longer count towards the final result. Rather the use of qualitative descriptors will be critical to evaluate student's learning journey. Furthermore by cutting down exams and testingsit will provide opportunities for schools the time and space to uplift the quality of teaching and learning. At the heart of this change, it emphasises the development and application of skills rather than theacquisition of knowledge. Learners move on to develop transferable skills that will be useful for further study and foryoung people as active citizens of the future. They learn to collaborate with others from another culture, community or country. They assess information critically and explore lines of reasoning. They learn to direct their own learning and develop an independence of thought.

In informing students that they are at-risk of failing certain subjects, their academic performance will be annotated and parents will continue to receive sufficient information about their child's progress through indicators such as subject marks and teachers' remarks which will still be included in the report books.

If we truly seek to become a change agent in educational system, educators need to rethink the teaching and learning approaches through multiple perspectives and reconstruct a richer and more balanced view about the essence of education. To be successful in life is not necessarily to aim for a highly developed personal attribute, but to endeavor for a heightened awareness that induces flexibility, energy, and vividness. It is not difficult to draw a distinction between an "innovative" teacher and an "instrumental" teacher. Innovative teachers attempt to shift from a teachercentered to a learning-centered approach. They have changed their teaching style by transforming lessons in accordance with the advantages technology can offer. Instrumental teachers seem to use technology as a "physical book". The distinction between the two groups has consequences for both the way lessons are delivered and how students experience them (Montrieuxet al 2015).

Only a responsible, caring attitude toward teaching makes for teaching competence of any kind. The teaching and learning should yield meaningful connections, drive impetus in teacher learning and transcend traditional disciplinary boundaries of the school curriculum. Myanmar teachers and students need inspiration and Myanmar like other developed countries needs creative teachers and students while also providing direction for future improvements in education.

\section{References}

AAAS(1990), Science for All Americans, Project 2061, Oxford University Press.

Albert, M. \& Beatty, B.J. (2014), Flipping the classroom applications to curriculum redesign for an introduction to management course: Impact on grades, Journal of Education for Business, 89(8), November, 419-424.

Anderson, L. W., Krathwohl, D. R., \& Bloom, B. S. (2001). A taxonomy for learning, teaching, and assessing: A revision of Bloom's taxonomy of educational objectives. New York: Longman.

Auerbach, S. (2012), School leadership for authentic family and community partnership. Research perspectives for transforming practice. Routledge, New York. NY 10017.

Basu, S.J., and Barton, A.C. (2007), Developing a Sustained Interest in Science among Urban Minority Youth, Journal of Research in Science Teaching, v. 44, pp. 466-489.

Beghetto, Ronald A.(2005), Does Assessment Kill Student Creativity? The Educational Forum, Vol. 69, Spring 2005.

Bergmann, J. \&Sams (2014), A.Flip Your Classroom: Reach Every Student in Every Class Every Day and the new Flipped Learning. Website http://www.flippedclassroomworkshop.com/ Accessed on 14 December 2018.

Biggs, J. (1999), Teaching for Quality Learning at University, Buckingham: Society for Research into Higher Education and the Open University Press.

Bogotch, I. (2002), Educational leadership and social justice: Practice into theory, Journal of School Leadership, 12(2), 138-156.

Bonwell, C.\& Eison, J. (1991), Active Learning: Creating Excitement in the Classroom AEHE-ERIC HigherEducation Report No. 1. Washington, D.C.: Jossey-Bass. 
Bouillion, L.M., and Gomez, L.M. (2001), Connecting School and Community with Science Learning: Real World Problems and School-Community Partnerships as Contextual Scaffolds, Journal of Research in Science Teaching, v. 38, pp. 878-898.

Brown, S. Rust, C. \& Gibbs, G. (1994), Strategies for Diversifying Assessment, Oxford: OCSD.

Bryan, L.A., and Atwater, M.M. (2002), Teacher Beliefs and Cultural Models: A Challenge for Science Teacher Preparation Programs, Science Education, v. 86, pp. 821-839.

Brew, A. (2003). Towards Autonomous Assessment: Using Self-Assessment and Peer Assessment. In Assessment Matters in Higher Education: Choosing and Using Diverse Approaches. Buckingham. The Society for Research into Higher Education \& Open University Press. pp. 159-171.

Buxton, C., Lee, O., and Santau, A. (2008), Promoting Science among English Language Learners: Professional Development for Today's Culturally and Linguistically Diverse Classrooms, Journal of Science Teacher Education, v. 19, pp. 495-511.

Churches, Andrew (2009), Bloom's Digital Taxonomy,

Website http://edorigami.wikispaces.com/file/view/bloom\%27s+Digital+taxonomy+v3.01.pdf Accessed on 13December 2018.

Davies, C.P. (2006), Implementing Earth Systems Science Curriculum: Evaluating the Integration of Urban Environments for an Urban Audience, Journal of Geoscience Education, v. 54, pp. 364-373.

Elder, L., and Paul, R. (2010) Critical Thinking Development: A Stage Theory - With Implications for Instruction, The Foundation for Critical Thinking.

Growe, R. (2011), The new inquiry in education: Reshaping the skill demands of today's students, Schooling, 2(1), 1-7.

Hare, W. (1999), Bertrand Russell on Critical Thinking, Journal of Thought 36,1,2001:7-16, and was first published in the Proceedings of the Twentieth World Congress of Philosophy (The Paideia Project On-line), 1999.

Hake, R.R. (1998), Interactive-engagement versus traditional methods: A six-thousand-student survey of mechanics test data for introductory physics courses. Am. J. Physics 66, 64-74.

Handelsman, J., Miller, S., and Pfund, C. (2007), Scientific teaching. New York: W.H. Freeman.

Hughes, I E (1995), Peer assessment of student practical reports and its influence on learning and skill acquisition. Capability. 1, 3943

Hui, Ming Fai (2003), Problems and Issues of the Teaching and Learning of Creativity in Hong Kong Schools, AsiaPacific Journal of Teacher Education \& Development June 2003, Vol. 6, No. 1, pp. 103-124.

Khan, F., Grube, E., Bernard, A. \& McCann, L. (2013), Distinguishing the interplay between technology and inverted (or flipped) teaching strategies, Midwest Academy of Management Proceedings, October, Milwaukee,WI.

Kolb, D. (1984), Experiential Learning: Experience as the source of Learning and Development, Englewoodcliffs, NJ, Prentice Hall.

Krathwohl, D. R. (2002), A revision of Bloom's taxonomy: An overview. Theory into practice, 41(4), 212-218.

Kujawa, S., \& Huske, L. (1995), The Strategic Teaching and Reading Project guidebook (Rev. ed.). Oak Brook, IL: North Central Regional Educational Laboratory.

Loh, Chee Yen Raymond and Teo, Teck Choon 2017), Understanding Asian students learning styles, cultural influence and learning strategies, Journal of Education \& Social Policy Vol. 7, No. 1; March 2017.

Marrs KA and Novak G. (2004), Just-in-Time Teaching in Biology: Creating an Active Learner Classroom Using the Internet. Cell Biology Education 3: 49-61.

Ministry of Education (Science and Technology) (2016).Website http://www.moe-st.gov.mm Accessed on 13 December 2018.

Moll, L.C., Amanti, C., Neff, D., Gonzalez, N. (1992), Funds of Knowledge for Teaching: Using a Qualitative Approach to Connect Homes and Classrooms. Theory into Practice, v. 31, pp. 132-141.

Montrieux H, Vanderlinde R, Schellens T, De Marez L (2015),Teaching and Learning with Mobile Technology: A Qualitative Explorative Study about the Introduction of Tablet Devices in Secondary Education,PLoS ONE 10(12): e0144008. https://doi.org/10.1371/journal.pone.0144008

Nagel, D. (2013) Report: Creativity Hindered in the Classroom by Testing, Mandates, Lack of Resources, The Journal.

National Research Council (2000), How People Learn: Brain, Mind, Experience and School, Bransford, J.D., Brown, A.L., and Cocking, R.R., eds. Washington, D.C.: National Academy Press.

Novak, G, Patterson, E.T., Gavrin, A.D., and Christian, W. (1999), Just-In-Time Teaching: Blending Active Learning with Web Technology,Upper Saddle River, NJ: Prentice Hall.

Paul, R. (2007), Critical Thinking in Every Domain of Knowledge and Belief, The 27th Annual International Conference on Critical Thinking, Keynote Address -- July 23, 2007

Paulson, D.R. (1999), Active learning and cooperative learning in the organic chemistry lecture class. J. Chem. Educ. 76, 1136-1140. 
Pellegrino, James W. and Hilton, M. (2012), Education for Life and Work: Developing Transferable Knowledge and Skills in the 21st Century, The National Academies Press, 500 Fifth Street, NW, Washington, DC 20001.

Phillips, C.R. and Trainor, J.E. (2014), Millennial students and the flipped classroom, Journal of Business andEducational Leadership, 5(1), 102-112.

Prensky, M. (2001), Digital natives, digital immigrants part 1. On the horizon, 9(5), 1-6.

Race, P. (2001), A Briefing on Self-, Peer, and Group Assessment, LTSN Generic Centre Assessment Series No. 9. York. LTSN Generic Centre.

Rivet, A.E., and Krajcik, J.S. (2008), Contextualizing Instruction: Leveraging Students' Prior Knowledge and Experiences to Foster Understanding of Middle School Science, Journal of Research in Science Teaching, v. 45, pp. 79-100.

Robinson, K. (2011), Out of our minds: Learning to be creative. John Wiley \& Sons

Roehl, A., Reddy, S. L. \& Shannon, G. J. (2013), The flipped classroom: An opportunity to engage millennial students through active learning strategies, Journal of Family and Consumer Sciences, 105(2), 44-48.

Schell, J. (2012), How do I get my students to prepare before coming to a flipped class? April 20 Best Practices, ConcepTests, Flipped classroom, Implementation, Just-in-Time-Teaching, Peer Instruction

Teo, Teck Choon and Low, Kim Cheng Patrick (2018),Reconstructing the Global Education and Learning Strategies to Enhance 21st Century Learning Skills: Learning Experience on a Global Perspective Across Curriculum, Journal of Education \& Social Policy Vol. 5, No. 2, June 2018.

Theoharis, G. (2009), The leadership our children deserve: 7 keys to equity, social justice, and school reform, New York: Teachers College Press.

Udovic, D., Morris, D., Dickman, A., Postlethwait, J., and Wetherwax, P. (2002), Workshop Biology: demonstrating the effectiveness of active learning in an introductory biology course. BioScience 52, 272-281.

Uekawa, K., Borman, K., and Lee, R. (2007), Student Engagement in U.S. Urban High School Mathematics and Science Classrooms: Findings on Social Organization, Race and Ethnicity, The Urban Review, v. 39, pp. 1-43. 